\title{
The Implementation of Visual, Auditory, Kinesthetic (VAK) Learning Model in Improving Students' Achievement in Writing Descriptive Texts
}

\author{
Oki Dwi Ramadian', Bambang Yudi Cahyono ${ }^{2}$, Nunung Suryati ${ }^{3}$ \\ ${ }^{1,2,3}$ Universitas Negeri Malang, Indonesia \\ okidwiramadian@gmail.com
}

\begin{abstract}
The English teaching in a public vocational school of Akomodasi Perhotelan (SMK AP) so far has shown unsatisfactory result. Based on the preliminary study it was found that the writing skill of the tent graders of SMK AP 3 was low. This classroom action research was aimed at improving the students' writing skill of descriptive text by implementing VAK learning model. In this study 26 students were selected as subjects. This study was completed through one cycle using VAK learning model. The findings revealed that students' writing scores increased after the researcher implemented the VAK learning model. The average score of the students improved 38.18 points into 81.49 compared to their scores in the preliminary study which was 43.31 . Out of 26 students, there were only 7 (26.92\%) who failed to achieve the minimum mastery criteria (KKM). It can be inferred from the findings that the VAK learning model succeeded in helping the students to improve their writing' achievement. The result of this study implies that VAK learning model can be an alternative to improve the students' writing skill.
\end{abstract}

Keywords: writing achievement, VAK learning model, visual, auditory, and kinesthetic

How to Cite: Ramadian, O. D., Cahyono, B. Y. and Suryati, N. (2019). The implementation of visual, Auditory, kinesthetic (VAK) learning model in improving students' achievement in writing descriptive texts. English Language Teaching Educational Journal, 2(3), 142-149.

\section{INTRODUCTION}

English is one of the most widely spoken languages. It is also one of the international languages used intensively for communication among people with different backgrounds. English language is considered as a foreign language in Indonesia. Moreover, it has been made into a compulsory subject that is taught in the Indonesian educational system, especially at the secondary levels.

In English language, there are four skills that need to be mastered which are: listening, speaking, reading, and writing. Reading and listening skills could be categorized as receptive skills in which according to Harmer (2001), it was stated that receptive skills are the ways in which people understand meaning from the expression they acquire from seeing or hearing. Besides, speaking and writing skills are categorized as productive skills in which according to Spratt, Pulverness and Williams (2005) productive skills are skills that involve producing the language rather than receiving it. To develop all four skills of the students through learning and teaching activities in classrooms, aside from matching with the core and basic competencies, these should be integrated in all levels of the teaching and learning process. Moreover, the process of those activities should be adhered to the core competences and the basic competences.

Writing is considered as one of the most difficult skills to acquire among those four English language skills (listening, speaking, reading and writing) (Huda, Hafifah, \& Wijaya, 2016; Warda, \& Wijaya, 2019; Soviyah \& Purwaningtias, 2018). The difficulties that the learners face while they learn writing subject are the difficulties in generating, organizing, and translating ideas into a readable text. Writing is considered difficult as it involves both highly complex skills such as planning and organizing text and lower level 
skills, for instance, spelling, punctuation, word choice, etc. Writing will be more difficult if the learner's language proficiency is weak (Richard \& Renandya, 2002). Heaton (1988) states that writing skill is a complex skill that requires mastery on both grammaticalrhetorical devices and also the conceptual and judgmental elements. However, it cannot be denied that writing is produced in many different forms and being used for a wide variety of purposes (Harmer, 2004) like for occupational or academic purposes and make people need to learn how to write correctly.

Similarly, the problems stated previously were also happening among the Grade X students of SMK AP 3 Malang. Based on the analysis of students' writing, it was found that their writing lacks using some particular things such as tenses, grammar, and vocabulary. Likewise, it showed that students were unaware of the organization and the language features of the descriptive texts.

There is one method that teachers can utilize to improve students' language skills especially writing namely visual, auditory, kinesthetic (VAK) learning model. Huda (2014), as cited in Wulansari (2016), emphasizes that the VAK learning model is a multisensory learning model that engages three learning styles. Furthermore, Rambe and Zainuddin (2014) state that the VAK is an approach and development of quantum learning that combine motivation, engagement, and cognitive processing habits of the students which then affect the use of metacognitive skills such as situation analysis, self-pacing, and selfevaluation to produce learning results according to the unique characteristics of the learning styles of students. According to Ahmed (2012) learning style is the attributes and preferred ways of collecting, understanding, arranging and processing information by a person. Similarly, Skehan (1991) as cited in Brown (2000) states "learning style is a general predisposition, voluntary or not, toward processing information in a particular way" (p. 31). Furthermore, Keefe (1979) as cited in Brown (2000) assumes that "learning styles might be thought of as 'cognitive, affective, and physiological traits that are relatively stable indicators of how learners perceive, interact with, and respond to the learning environment" (p. 54). There are three main types of learning styles, to wit; visual, auditory, and kinesthetic. This study focuses on accommodating the VAK learning style, which is the combination of those three main learning styles, visual, auditory, and kinesthetic (VAK) to develop students' achievement in writing.

Table 1. The Activities Suitable for the Students' Learning Style Preference

\begin{tabular}{|c|c|c|}
\hline Visual Learners & Auditory Learners & Kinesthetic Learners \\
\hline Drawing or painting. & Listening to talks and & Writing word several \\
\hline Using visual objects & lectures. & times and making writt \\
\hline such as diagrams, video, & Saying the words while & $\begin{array}{l}\text { notes. } \\
\text { Movino }\end{array}$ \\
\hline maps, etc. & Providing & studying. \\
\hline $\begin{array}{l}\text { Showing the concrete } \\
\text { forms of words and }\end{array}$ & $\begin{array}{l}\text { instructions since they are } \\
\text { good in receiving it. }\end{array}$ & $\begin{array}{l}\text { Discussing idea } \\
\text { others. }\end{array}$ \\
\hline & Playing on recorded audio & \\
\hline Writing out notes for & pes etc & \\
\hline $\begin{array}{l}\text { frequent and quick } \\
\text { visual scan and review. }\end{array}$ & $\begin{array}{l}\text { Repeating and rehearsing } \\
\text { information many times } \\
\text { to get the sound. }\end{array}$ & \\
\hline
\end{tabular}

Source: Wood (2000) and Reid (2005) 
Fleming (2006) as cited in Wong (2015) has conducted a learning style survey and found out that: a) individual behaviors can be affected by the individual learning style preferences, b) the findings enable the teachers to create better teaching and learning strategies that are suitable with the students' learning style, c) strategies that are suitable for learners' learning style preferences can motivate them, d) the suitability of students' learning styles and learning strategies can enhance deeper approaches to effective learning and metacognition, and d) it is important to understand learners' learning styles.

Some researchers who were interested in confirming Fleming's finding conducted some studies about VAK learning model. Rambe and Zainuddin (2014) showed that VAK learning model significantly affected students' achievement in writing especially writing recount text. Another study conducted by Lista, Atmowardoyo, and Salija (2015) also proved that the VAK was effective to improve students' writing ability.

Kazemi, Zafarghand, and Tahriri (2016) also investigated the effect of learning styles (visual, auditory, and kinesthetic) in language learning. They concluded that style preference in language learning is a significant factor fostering the learning process. Furthermore, they stated that it is beneficial to teach language elements that suit the students' preferred learning style. Besides, Suhara (2013) also conducted an experimental research in Junior High School 1 Lawang class X in South Sumatra. The result has also proven that the VAK learning model effectively improved the students' skill in writing descriptive texts.

Based on a decree of the Ministry of Education and Culture of Indonesia number 24, 2016 related to core competences and basic competences of every subject in the 2013 Curriculum, students of upper secondary school, including senior high schools (Sekolah Menengah Atas), vocational high schools (Sekolah Menengah Kejuruan), and Islamic senior high schools (Madrasah Aliyah) and any other kind of upper secondary schools, should learn the varieties of texts including descriptive text.

Descriptive text is a text which describes person, place, or mood (Nawawi, 2011). As the descriptive text is compulsory for the upper secondary school, teachers should focus on the teaching of this topic in their syllabuses. It is obviously true that we need to improve students' writing skills, especially for descriptive texts. This motivated the conduct of this study, specifically to answer the problem: How can the visual, auditory, kinesthetic (VAK) learning model improve students' achievement in writing descriptive texts?

\section{RESEARCH METHOD}

The research design of this study is classroom action research (CAR). CAR is a research study which is usually conducted in a particular social situation that requires the researcher to do self-reflective enquiries. The objective of this type of study is to improve understanding and enable the researcher to do self-reflections toward their own performances, their understanding of these practices, and the situations in which the work is carried out (Carr \& Kemmis, 1986). Burns (2010) explains more about the definition of action research (AR). She says that AR involves taking a self-reflective, critical, and systematic approach to explore the teaching contexts. Furthermore, Kemmis and McTaggart (1988) as cited in Burns (2010) say that action research employs four steps: planning, action, observation, and reflection. The process of planning activities involves (1) designing the lesson plan, (2) preparing the materials, (3) preparing the research instruments and (4) setting the schedule to conduct the study and the criteria of success. 
Table 2. The Criteria for Success

\begin{tabular}{l|l|l|l}
\hline Criterion & Data & Data Source & \multicolumn{2}{|l}{ Data Collection } \\
\hline $\begin{array}{l}\geq 70 \text { of the students } \\
\text { achieve the } \\
\text { standard minimum } \\
\text { mastery of 75. }\end{array}$ & $\begin{array}{l}\text { The after } \\
\text { score } \\
\text { implementing the } \\
\text { action. }\end{array}$ & $\begin{array}{l}\text { Students written } \\
\text { output. }\end{array}$ & $\begin{array}{l}\text { Scoring } \\
\text { students written } \\
\text { output. }\end{array}$ \\
\hline
\end{tabular}

Action refers to the implementation of the strategy that had been planned. The researcher, who was the teacher of the class, took the role of applying the VAK learning model in class. As the teacher, I observed both the learning and teaching processes. This is done to ascertain whether the VAK learning model is suitable or not and to see whether the learning and teaching process follows the plan or not.

Besides implementing the action, I also observed the process. I observed the students while doing the VAK activities. The data came in the form of description of what was happening in the class during the implementation the VAK learning model. Besides, I also observed the situation of the class. I also wrote what I felt while applying the VAK learning model. The data were used as some of the consideration to evaluate the learning and teaching that were conducted.

The final step of this classroom action research involved reflecting of the actions done in class. I analyzed the collected data from the preliminary study and the actual implementation of the learning model. The results were compared to know the differences. If students' scores increased and reached minimum mastery criteria of 75 , after the implementation of the VAK learning model, then it may be concluded that the VAK learning model helped improve students' writing skill, specifically to write descriptive texts. Conclusions were then made from the results of the analysis.

\section{FINDINGS}

I found that the students' average writing score in the preliminary study was 43.31 . This indicated that most of the students failed achieving the minimum mastery criteria that I set which was $\geq 75$. There was only one student $(3.84 \%)$ who was able to reach this standard; on the other hand, the rest 25 students $(96.15 \%)$ failed.

After the implementation of the VAK learning model, the students' writing scores increased. I found that most of the students were able to achieve the minimum mastery criteria. Out of 26 students, there were seven students (26.92\%) who failed achieving the standard. Despite, the number of the students who achieved or passed the standard was high, 19 students or $73.07 \%$. Moreover, in terms of the total average score, it showed a significant improvement. The mean score of the students in this writing descriptive text was 81.49 . 


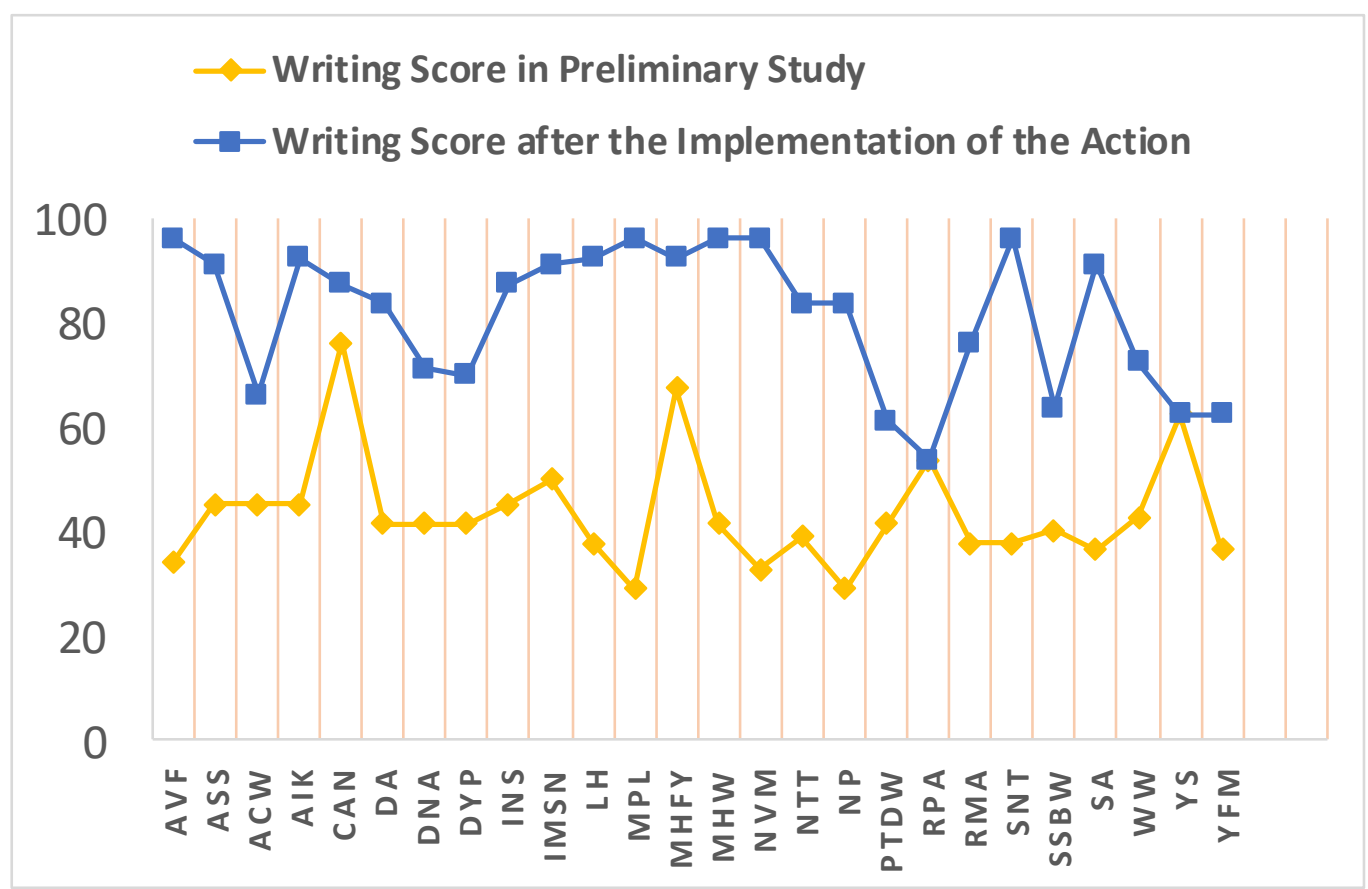

Figure 1. The Improvement of the Students' Writing Score

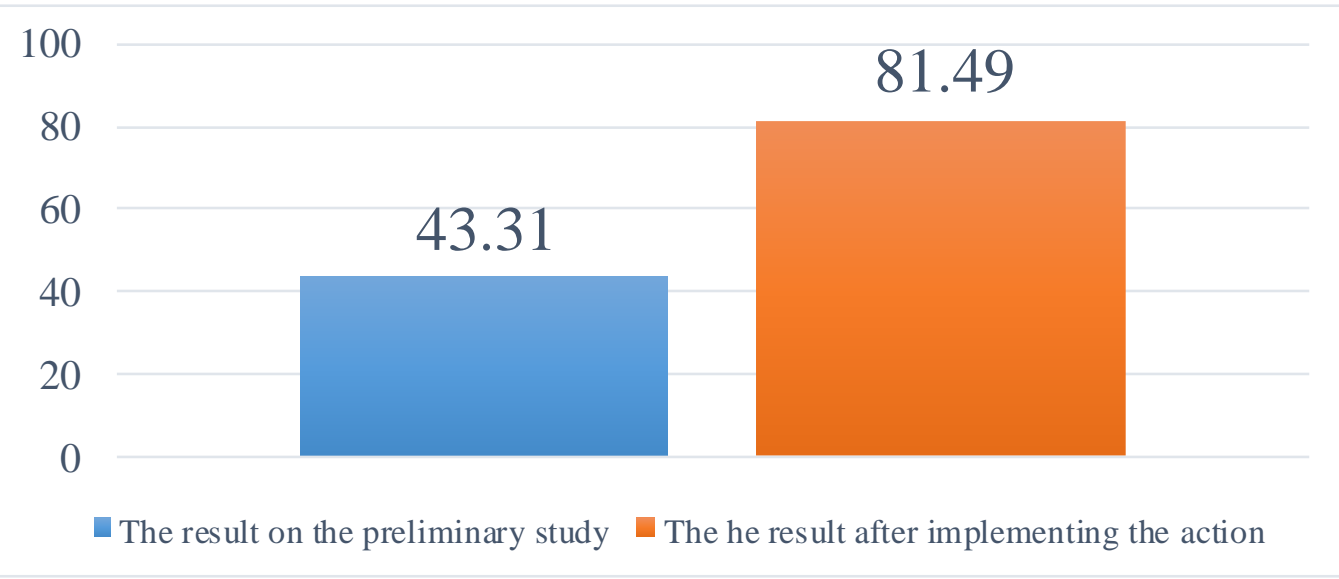

Figure 2. The Mean Scores of before and after the Action

After the implementation of VAK learning model the minimum mastery criteria was reached by the students. The action was considered successful since $\geq 70$ of the students achieved the minimum mastery criteria which was 75 . Based on the findings, the number of the students who were able to achieve or pass the minimum mastery criteria after the implementation of VAK learning model was 19 students $(73.07 \%)$. It proved that the strategy of integrating the VAK learning model was successful in developing the students writing' skill in writing descriptive texts. 


\section{DISCUSSION}

There were some improvements on the students' writing achievement according to the findings in terms of the students' writing scores. Out of 26 students, there were 19 students $(73.07 \%)$ who achieved the minimum mastery criteria I set although there were seven students $(26.92 \%)$ who failed reaching the standard. However, the percentage of the students who succeeded to achieve the minimum mastery criteria was higher than the students who were not able to reach the standard, meaning that the VAK learning model brought some improvements to the students' writing skill. This study supported the findings of the previous studies such as those conducted by Rambe and Zainuddin (2014), Lista, Atmowardoyo, and Salija (2015), and Suhara (2013).

On the study that was conducted by Rambe and Zainuddin (2014), the result was that the VAK learning model significantly affects the students' achievement in writing especially writing recount text. The result of this current study was in line with Rambe's and Zainuddin's (2014) finding. The difference was only that on this present study the VAK learning model managed to develop the student's writing achievement in terms of writing a descriptive text. Furthermore, the findings of this current study was also in line with the study of Lista, Atmowardoyo, and Salija (2015) that indicated that VAK learning model was useful to improve the students' writing skill.

There were some aspects of improvements in students' writing skill such as writing organization, content, and language. In terms of the organization, the learning model enabled the students to realize the correct organization of the descriptive text. Furthermore, during the implementation of the action, the learning model made the students remember that the organization of the descriptive text consists of twofold namely identification and description. This information was repeated few times through some activities related to three learning style activities. These activities were "Listen and Send" and "Make the Poster."

In terms of content, VAK learning model also helped the students to find the correct way to convey a clear topic. Through the use of this learning model, especially in the "Use Your Body to Describe", the students were trained to make a clear topic sentence. The students were trained to make a topic sentence by choosing a particular tourism place, then they made particular tourism place into a noun phrase and finally, they made a sentence by adding the adjective. Furthermore, this activity required the students to move their body that enabled them to remember the sentence because the movement became a clue.

Similarly, the language in the learning style also trained the students to fulfill the language features which were required to make a descriptive text. Some of the language features of descriptive text have simple present tense form and employ many noun phrases and adjectives. Through the "Use Your Body to Describe" activity, the students were trained to make the noun phrase. After that, the students were asked to put an adjective after the noun phrase that made the sentence turned into a simple present tense.

Through the training provided by the VAK learning model, the students found the right form of a simple present tense. The simple present tense was taught deductively trough the VAK activities, "Use Your Body to Describe". This activity avoided the students from making grammatical errors. Some grammatical errors were found during the activities but I, as a teacher, gave feedback to response the wrong form of the noun phrase or the sentence. The "Use Your Body to Describe" enabled the students to practice a lot.

After the teaching and learning activities ended, the students obtained knowledge related to descriptive text and how to write one of the descriptive texts related to tourism place. Although there were seven students (26.92\%) out of 26 students who failed reaching the minimum mastery criteria, the number of the students who were able to reach the 
standard was higher, i.e. 19 students $(73.07 \%)$. This proved that the VAK learning model was helpful to improve the students' writing skill.

All of the findings explained above matched with the theory that Kazemi, Zafarghand, and Tahriri (2016) which stated that, in language learning, style preference is a significant factor which fosters the learning process.

\section{CONCLUSION}

The findings of this study highlighted the practical advantage of the VAK learning model to the classroom as it helped to increase students' achievement in writing descriptive texts. The achievement of standard scores in all of the criteria set by the majority X Graders of SMK HA3 Malang including students' mean scores are indicated with the VAK learning model. The VAK learning model played a relevant role in the reinforcement of knowledge among students who became the participants of this study and trained the students in writing descriptive texts. The core activities found to be facilitative in developing students' writing skill involved students' bodily movements and group interaction.

\section{REFERENCES}

Ahmed, O. N. (2012). The effect of different learning styles on developing writing skills of EFL, Saudi Learners. British Journal of Arts and Social Sciences 5(2), 220-233. Retrieved from https://pdfs.semanticscholar.org/6267/a0911a77d92c2ce8ac24901996c0d69c6121.p $\underline{\mathrm{df}}$

Barsch, J. (1991). Activity: Barsch Inventory. The IRIS Center Peabody College Vanderbilt University Nashville. https://iris.peabody.vanderbilt.edu/module/udl/cresource/q1/p01/activity-barschinventory/. Accessed December 27th 2017

Brown H.D. (2000). Principles of Language Learning, Fourth Edition. New York: Addison, Wesley, Longman

Burns, A. (2010). Doing Action Research in English Language Teaching: A Guide for Practitioners. New York: Routledge.

Carr, W., \& Kemmis, S. (1986). Becoming Critical Education: Knowledge and Action Research. New York: Routledge Falmer.

Harmer, J. (2001). The Practice of English Language Teaching. Addison Wesley Publishing Company: Longman.

Harmer, J. (2004). How to Teach Writing. Harlow, United Kingdom: Pearson Education Limited.

Heaton, J. B. (1988). Writing English Language Tests. New York: Longman Group UK Limited.

Huda, M., Hafifah, G. N., \& Wijaya, A. (2016). The implementation of flash games in teaching writing descriptive text to the seventh grade of SMP Muhammadiyah 10 Surabaya. Tell: Teaching of English Language and Literature Journal. 4 (2), 99116. doi:10.30651/tell.v4i2.2104 
Kazemi, S., Zafarghand, A., \& Tahriri, A. (2016). The relationship between learning styles and vocabulary recall among sensorineural hearing loss EFL learners. Journal of Applied Linguistics and Language Research, 3 (4), 325-346. Retrieved from http://www.jallr.com/index.php/JALLR/article/view/360/pdf360

Lista, L., Atmowardoyo, H., \& Salija, K. (2015). The effects of visual auditory kinesthetic learning style as technique in improving students' writing ability. ELT Worldwide, 2 (2), 62-76.

Nawawi, M.B. (2011) Improving Students' Writing Skill of Descriptive Text Through Guided Questions (A Classroom Action Research at VIII-8 class of SMP PGRI 1 Ciputat-Kota Tangerang Selatan). (Unpublished Thesis). Department of English Education. Faculty of Tarbiyah and Teachers Training. UIN Syarif Hidayatullah Jakarta.

Rambe, H. H., \& Zainuddin. (2014). The Effect of Using Visual, Auditory, Kinesthetic (VAK) Learning Model on Students' Achievement in Writing Recount Text. $\begin{array}{lllll}\text { REGISTER } & 3 & (4), & 340-351 & \text { Retrieved from }\end{array}$ https://jurnal.unimed.ac.id/2012/index.php/eltu/article/download/1385/1144

Reid G. (2005). Learning Styles and Inclusion. London: Paul Chapman Publishing.

Richards, J. C., \& Renandya, W. A. (2002). Method in language teaching an anthology of current practice. New York: Cambridge University Press.

Spratt, M., Pulverness, A., \& Williams, M. (2005). The TKT Course: Teaching Knowledge Test. London: Cambridge University Press.

Soviyah, Purwaningtias, Y.(2018). Old but gold: The use of picture cues to teach writing (an experimental research). English Language Teaching Educational Journal, 1(1), 38-48. DOI: 10.12928/eltej.v1i1.265

Suhara, A.M. 2013. Keefektifan model VAK (visualization auditory kinestetic) dalam pembelajaran menulis deskriptif (studi eksperimen pada siswa kelas x SMA Negeri 1 Lawang Kidul Sumatera Selatan (Unpublished Thesis) Universitas Pendidikan Indonesia.

The Decree of Minister of Education and Culture of Indonesia Number 24, year 2016.

Warda, E. G. \& Wijaya, A. (2019) The effectiveness of teaching writing descriptive text by using social media "Instagram" to improve students' writing ability at junior high school students. Tell: Teaching of English Language and Literature Journal. 7 (1), 16-24, Doi: $\underline{10.30651 / \text { tell.v7i1.2696 }}$

Wong, W.L.H. (2015). A study of language learning style and teaching style preferences of Hong Kong community college students and teachers in English for academic purposes (EAP) contexts (Unpublished Thesis). School of Teacher Education. College of Education, Health and Human Development University of Canterbury.

Wood, G. (2000). How to study second edition use your personal learning style to help you succeed when it counts. New York: Learning Express, LLC.

Wulansari, Y. (2016) The use of visual auditory kinesthetic (VAK) learning model to improve students' reading comprehension (Unpublished Thesis). Department of Teacher Training and Education Faculty State Institute for Islamic Studies (IAIN) Salatiga. 